\title{
Traditional plant treatments for diabetes. Studies in normal and streptozotocin diabetic mice
}

\author{
S. K. Swanston-Flatt ${ }^{1}$, C. Day ${ }^{2}$, C. J. Bailey ${ }^{2}$ and P.R. Flatt ${ }^{1}$ \\ ${ }^{1}$ Biomedical Sciences Research Centre, and Department of Biological and Biomedical Sciences, University of Ulster, Coleraine, and \\ 2 Department of Pharmaceutical Sciences, Aston University, Birmingham, UK
}

\begin{abstract}
Summary. The effects on glucose homeostasis of eleven plants used as traditional treatments for diabetes mellitus were evaluated in normal and streptozotocin diabetic mice. Dried leaves of agrimony (Agrimonia eupatoria), alfalfa (Medicago sativa), blackberry (Rubus fructicosus), celandine (Chelidonium majus), eucalyptus (Eucalyptus globulus), lady's mantle (Alchemilla vulgaris), and lily of the valley (Convallaria majalis); seeds of coriander (Coriandrum sativum); dried berries of juniper (Juniperus communis); bulbs of garlic (Allium sativum) and roots of liquorice (Glycyrhizza glabra) were studied. Each plant material was supplied in the diet $(6.25 \%$ by weight) and some plants were additionally supplied as decoctions or infusions $(1 \mathrm{~g} / 400 \mathrm{ml})$ in place of drinking water to coincide with the traditional method of preparation. Food and fluid intake, body weight gain, plasma glucose and insulin concentrations in normal mice were not altered by 12 days of treatment with any of the plants. After administration of streptozotocin ( $200 \mathrm{mg} / \mathrm{kg}$ i.p.) on day 12 the development of hyperphagia, polydipsia, body weight
\end{abstract}

loss, hyperglycaemia and hypoinsulinaemia were not affected by blackberry, celandine, lady's mantle or lily of the valley. Garlic and liquorice reduced the hyperphagia and polydipsia but did not significantly alter the hyperglycaemia or hypoinsulinaemia. Treatment with agrimony, alfalfa, coriander, eucalyptus and juniper reduced the level of hyperglycaemia during the development of streptozotocin diabetes. This was associated with reduced polydipsia (except coriander) and a reduced rate of body weight loss (except agrimony). Alfalfa initially countered the hypoinsulinaemic effect of streptozotocin, but the other treatments did not affect the fall in plasma insulin. The results suggest that certain traditional plant treatments for diabetes, namely agrimony, alfalfa, coriander, eucalyptus and juniper, can retard the development of streptozotocin diabetes in mice.

Key words: Antihyperglycaemic plants, glucose homeostasis, traditional treatments for diabetes, streptozotocindiabetic mice.
The known use of plant treatments for diabetes dates from the Ebers papyrus of about $1550 \mathrm{BC}$. Many traditional plant treatments for diabetes are used throughout the world [1]. After the introduction of insulin therapy the use of traditional treatments for diabetes greatly declined in occidental societies, although some traditional practices are continued for prophylactic purposes and as adjuncts to conventional therapy [1]. In areas of the developing world in which conventional medicines are not readily available, traditional treatments for diabetes remain the major form of therapy. Few of the traditional plant treatments for diabetes have received scientific or medical scrutiny, and the World Health Organisation has recommended that this area warrants attention [2]. This paper describes a study of indigenous and non-indigenous plants recommended in European folklore medicine as beneficial in the treatment of diabetes.

\section{Materials and methods}

\section{Animals}

Adult male mice from a colony bred at Aston University [3] were housed at $22 \pm 2{ }^{\circ} \mathrm{C}$ in an air conditioned room and supplied with a standard pellet diet (Spratts Laboratory Diet 1, Lillico Ltd, Reigate, UK) and water ad libitum.

\section{Traditional antidiabetic plants}

Dried leaves of alfalfa (Medicago sativa), agrimony (Agrimonia eupatoria), blackberry (Rubus fructicosus), celandine (Chelindonium majus), eucalyptus (Eucalyptus globulus), lady's mantle (Alchemilla vulgaris) and lily of the valley (Convallaria majalis); seeds of coriander (Coriandrum sativum); dried berries of juniper (Juniperus communis); bulbs of garlic (Allium sativum) and the dried roots of liquorice (Glycyrrhiza glabra) were purchased from retail health 


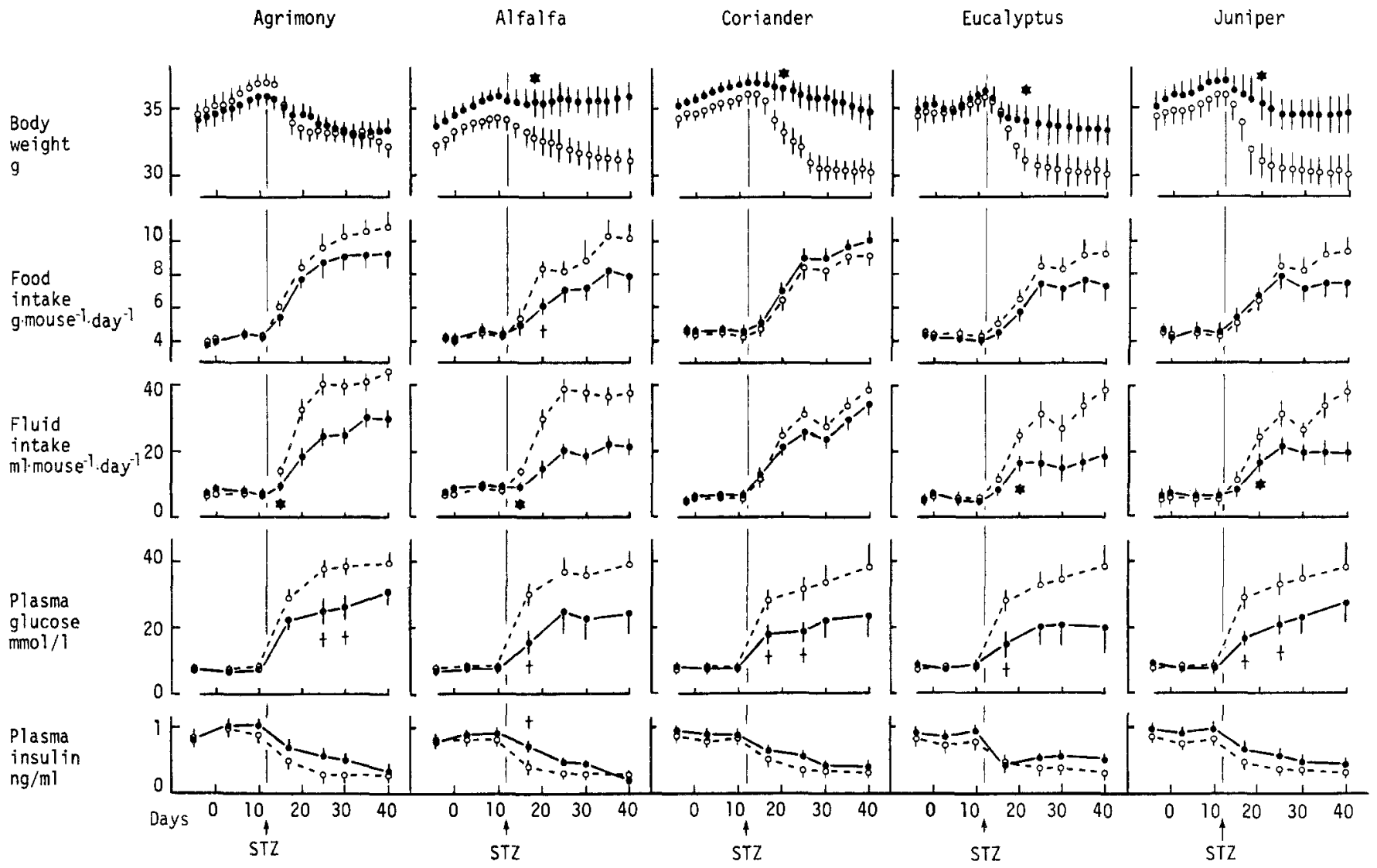

Fig. 1. Effect of agrimony, alfalfa, coriander, eucalyptus and juniper $(6.25 \%$ by weight of diet, plus $1 \mathrm{~g} / 400 \mathrm{ml}$ as a decoction or infusion in place of drinking water as detailed in Materials and methods) on body weight, food and fluid intake and plasma glucose and insulin concentrations in non-diabetic (days $0-12$ ) and streptozotocin (STZ) diabetic (days 12-40) mice. Control 0---o; Test $\bullet$. Values are mean \pm SEM of groups of 5-7 mice. $+p<0.05$ compared with control at this time. ${ }^{*} p<0.05$ compared with control at this time and all subsequent times during this study

food stores in Birmingham, UK. All plant treatments were supplied as $6.25 \%$ by weight of the diet, by mixing homogenised plant material with powdered diet and repelleting. In addition agrimony, blackberry, eucalyptus, garlic and liquorice were supplied as decoctions, prepared by adding $1 \mathrm{~g}$ of plant material to $400 \mathrm{ml}$ of cold water, which was boiled for $5 \mathrm{~min}$ and infused for $15 \mathrm{~min}$. Alfalfa, celandine, coriander, juniper, lady's mantle and lily of the valley were supplied as infusions prepared by adding $1 \mathrm{~g}$ of plant material to $400 \mathrm{ml}$ of boiling water and infusing for $15 \mathrm{~min}$. Decoctions and infusions were supplied in lieu of drinking water. Food and fluid were supplied ad libitum. In preliminary experiments control diets were supplemented with fibre (methyl cellulose) to correspond with the fibre content of the test diet. Since the small amounts of methyl cellulose involved ( $<6 \%$ by weight of the diet) did not affect the parameters studied compared with non-supplemented diet this practice was not continued.

\section{Experimental procedure}

After a 4 day run-in period, groups of 5-7 normal mice were supplied with a traditional plant treatment in the diet and as an infusion or decoction in the drinking water. Treatment was maintained throughout the experiment. Diabetes was induced on day 12 by ad- ministration of streptozotocin (Sigma Chemical Company, Poole, Dorset; $200 \mathrm{mg} / \mathrm{kg}$ i.p. in $0.5 \mathrm{~mol} / \mathrm{l}$ citrate buffer, $\mathrm{pH} 4.5$ ). Body weight, food and fluid intake were monitored daily. Blood samples $(50 \mu \mathrm{l})$ for plasma glucose and insulin determination were obtained from the tail tip of conscious mice on days $-4,3,10,17,24,30$ and 40 .

\section{Statistical analysis}

Plasma glucose was assayed using a glucose oxidase method and plasma insulin was determined by a dextran-charcoal radioimmunoassay using crystalline mouse insulin (Novo Industri, Copenhagen, Denmark) as standard [3]. Groups of data are expressed as mean $\pm S E M$ and compared using ANOVA and Student's $t$-test. Differences were considered to be significant if $p<0.05$.

\section{Results}

None of the plant treatments significantly altered any of the parameters measured (body weight, food and fluid intake, basal plasma glucose and insulin) during the 12 days of administration to normal mice (selected examples in Fig. 1).

Induction of diabetes with streptozotocin was associated with the characteristic development of hyperglycaemia, hyperphagia, polydipsia, insulinopenia and loss of body weight (see control values after day 12 in Fig.1).

Treatment with blackberry, celandine, garlic, lady's mantle, lily of the valley and liquorice did not significantly affect basal plasma glucose and insulin concentrations in streptozotocin diabetic mice (data not shown). However, 
garlic and liquorice consistently reduced both the hyperphagia (about $15 \%$ and $20 \%$ respectively) and the polydipsia (about $40 \%$ and $45 \%$ respectively) compared with controls (data not shown), and garlic reduced body weight loss (decrease in body weight of $2 \%$ by day 40 compared with a $14 \%$ decrease in control group; data not shown).

Treatment with agrimony, alfalfa, coriander, eucalyptus and juniper consistently lowered mean values for basal plasma glucose concentrations in the diabetic mice. These values achieved statistical significance compared with controls as shown in Figure 1. With the exception of coriander these plants reduced fluid intake, but only alfalfa significantly reduced food intake (Fig.1). Body weight loss in the diabetic mice was reduced by alfalfa, coriander, eucalyptus and juniper. Basal plasma insulin concentrations were not consistently affected by any of the treatments, although alfalfa initially countered the hypoinsulinaemic effect of streptozotocin.

\section{Discussion}

Use of the plants studied herein as traditional treatments for diabetes has been described in various accounts of folklore medicine $[4,5]$, but most of the evidence for their beneficial effects is anecdotal. However a hypoglycaemic effect of alfalfa has been observed in an insulin-dependent diabetic patient [6], and hypoglycaemic effects of blackberry [7], coriander [7] and garlic [8,9] have been reported in normal and alloxan diabetic animals.

The present study has investigated a possible hypoglycaemic effect of these traditional plant treatments using the streptozotocin diabetic mouse which serves as a model of hypoinsulinaemia and insulin resistance [10]. Consumption of large amounts $(6.25 \%$ by weight of the diet plus decoctions or infusions $(1 \mathrm{~g} / 400 \mathrm{ml})$ as drinking fluid) of blackberry, celandine, garlic, lily of the valley and liquorice did not affect the parameters of glucose homeostasis studied. However garlic and liquorice reduced the hyperphagia and polydipsia. Garlic also reduced the body weight loss in streptozotocin diabetic mice and gave the mice a healthier appearance, as indicated by coat condition and physical activity. This suggests that garlic might provide benefits other than glycaemic control.

Plants which reduced the hyperglycaemia of streptozotocin diabetic mice (agrimony, alfalfa, coriander, eucalyptus and juniper) generally reduced the polydipsia (except coriander) and the loss in body weight (except agrimony). Alfalfa, which also reduced the hyperphagia, countered the initial insulinopenic effect of streptozotocin suggesting that this plant might offer some protection against islet Beta-cell destruction. The use of alfalfa as a traditional treatment for diabetes has been attributed at least in part to the high concentration of manganese in this plant [6]. Manganese chloride can exert a hypoglycaemic action [6], and this may be of particular benefit in diabetic conditions of manganese deficiency. Whether manganese contributes to the antidiabetic action of alfalfa in streptozotocin diabetic mice is unestablished. The literature offers no indication of the possible substances or modes of action responsible for the hypoglycaemic effects of agrimony, coriander, eucalyptus and juniper, but this study suggests that treatment with these plants does not significantly affect plasma insulin concentrations.

Acknowledgements. These studies were supported by the British Diabetic Association. The authors acknowledge the excellent assistance of Ms. J. Crouch, Ms. L. Dowthwaite, Ms. A. Thompson and Ms. H.Udall.

\section{References}

1. Bailey CJ, Day C (1989) Traditional treatments for diabetes. Diabetes Care 12:553-564

2. WHO expert committee on Diabetes Mellitus (1980) Second report. Technical report series 646. World Health Organisation, Geneva, p 61

3. Flatt PR, Bailey CJ (1981) Abnormal plasma glucose and insulin responses in heterozygous lean $(\mathrm{ob} /+)$ mice. Diabetologia 20: 573-577

4. Sfikas G (1979) Medicinal Plants of Greece. Efstattiadis Group, Athens, $\mathrm{p} 145$

5. Duke JA (1985) Handbook of medicinal herbs. CRCPress, Boca Raton, Florida, p 550

6. Rubenstein AH, Levin NW, Elliott GA (1962) Manganese-induced hypoglycaemia. Lancet II: 1348-1356

7. Sharaf AA, Hussein AM, Mansour MY (1963) The antidiabetic effect of some plants. Planta Med 11:159-168

8. Brahmachari HD, Augusti KT (1962) Orally effective hypoglycaemic agents from plants. J Pharm Pharmacol 14: 254-255

9. Jain RC, Vyas CR, Mahatma OP (1973) Hypoglycaemic action of onion and garlic. Lancet II: 1491

10. Bailey CJ, Flatt PR (1986) Animal models of diabetes. In: Nattrass M (ed) Recent advances in diabetes, Vol.2. Churchill Livingstone, Edinburgh, pp 71-89

Received: 25 January 1990

and in revised form: 17 April 1990

Prof. P.R. Flatt

Department of Biological and Biomedical Sciences

University of Ulster

Coleraine, BT52 1SA

Northern Ireland

UK 